\title{
Forest floor contribution to phosphorus nutrition: experimental data
}

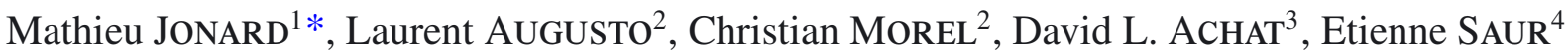 \\ ${ }^{1}$ Université catholique de Louvain, Faculté d’Ingénierie Biologique, Agronomique et Environnementale, \\ Unité des Eaux et Forêts, Croix du sud 2/009, 1348 Louvain-la-Neuve, Belgium \\ ${ }^{2}$ INRA, UMR 1220 TCEM (INRA-ENITA), avenue E. Bourlaux 71 BP81, 33883 Villenave d'Ornon, France \\ ${ }^{3}$ ENITA de Bordeaux, UMR 1220 TCEM (INRA-ENITA), avenue E. Bourlaux 71 BP 81, 33883 Villenave d'Ornon, France \\ ${ }^{4}$ ENITA de Bordeaux, UMR 1220 TCEM (INRA-ENITA), cours du Général de Gaulle 1, CS 40201, 33175 Gradignan, France
}

(Received 19 December 2008; accepted 12 January 2009)

Keywords:

isotopic tracer /

Pinus pinaster /

P uptake /

$P$ release and retention /

sandy podzol
Mots-clés :

traceur isotopique /

Pinus pinaster /

prélèvement en $\mathbf{P}$ /

libération et rétention du $\mathbf{P}$ /

podzol sableux

\begin{abstract}
- Although accumulation of decomposing litter temporarily removes nutrients from active circulation, it creates a medium that is more suitable for nutrient uptake where soil conditions are unfavorable. - A pot experiment was conducted using labeling of isotopically exchangeable phosphate ions of the soil and applying the dilution principle to accurately assess the contribution of the forest floor to $\mathrm{P}$ nutrition of maritime pine seedlings (Pinus pinaster Aït.). Three-week-old maritime pine seedlings were planted in pots containing either mineral soil (MS) or mineral soil covered with a forest floor layer (MS+FF).

- After $130 \mathrm{~d}, \mathrm{P}$ uptake was still insignificant in the MS treatment while the P content of the seedlings in the MS+FF treatment increased tenfold with respect to the initial P content. In the latter treatment, the forest floor contributed $99.1 \%$ of the P supply to pine seedlings.

- The higher P uptake from the forest floor than from the mineral soil may be explained by its lower ability to retain inorganic $\mathrm{P}$, which enabled a higher concentration of inorganic $\mathrm{P}$ to be maintained in solution.
\end{abstract}

Résumé - Contribution des couches holorganiques à la nutrition en phosphore : données expérimentales.

- Bien que l'accumulation de litière en décomposition immobilise temporairement une partie des nutriments, elle crée un espace propice au prélèvement des nutriments là où le sol minéral est peu favorable.

- La contribution des couches holorganiques à la nutrition en $\mathrm{P}$ de semis de pin maritime (Pinus pinaster Aït.) a été estimée sur base d'une expérience en pots combinée à un marquage des ions phosphate du sol minéral. Des semis de trois semaines ont été plantés dans des pots contenant soit uniquement du sol minéral (MS) ou soit du sol minéral recouvert par une couche de litière (MS+FF). - Après 130 jours, le prélèvement en $\mathrm{P}$ était toujours insignifiant dans le traitement MS alors que le contenu en P des semis du traitement MS+FF avait été décuplé par rapport au contenu initial. Dans ce traitement, la contribution des couches holorganiques à l'alimentation en phosphore des semis était de $99,1 \%$.

- Le prélèvement en $\mathrm{P}$ plus important à partir des couches holorganiques peut être expliqué par leur faible capacité de rétention du $\mathrm{P}$ qui permet de maintenir une forte concentration en $\mathrm{P}$ dans la solution du sol.

\footnotetext{
*Corresponding author: Mathieu.jonard@uclouvain.be
} 


\section{INTRODUCTION}

Many of the world's forests grow on unfertile soils (Kimmins, 1997). To adapt to such conditions of nutritional stress, tree species have evolved a number of different strategies: (i) low nutrient demand, (ii) mechanisms for nutrient retention, such as efficient internal recycling, persistent foliage, leaching-resistant cuticles and chemical defenses against herbivores, and (iii) mycorrhizal association (Chapin, 1980). In addition, nutrient recycling and retention within the ecosystem play a major role in the preservation of soil chemical fertility in nutrient-poor ecosystems. A large proportion of the nutrients taken up during the growing season are returned to the soil through litterfall and are then progressively released during decomposition (Attiwill and Adams, 1993). The litter decomposition rate is thus generally considered to be a key ecosystem parameter; if decomposition is slow, litter accumulates and the associated nutrients are removed from active circulation for a certain time, which is thought to reduce nutrient cycling and forest productivity (Berg and McClaugherty, 2003; Fisher and Binkley, 2000; Kimmins, 1997). On the other hand, the accumulation of decomposing litter may be considered as a way to improve nutritional conditions. According to Northup et al. (1995), coniferous trees in the Pigmy forest in California increase their foliar phenolic concentration with soil acidity in order to favor litter accumulation. This adaptation limits the loss of nutrients due to leaching and creates a medium that is more suitable for nutrient uptake where mineral soil conditions are unfavorable. Indeed, trees may improve the nutritional status of the uppermost part of the soil by extracting nutrients from the mineral soil horizons and by concentrating them in the forest floor (Brandtberg et al., 2004). The capital of nutrients accumulated at the soil surface during the development of the forest floor is then preferentially used by trees (Ploglase et al., 1992); this mechanism allows trees to shorten the cycling of nutrients such as $\mathrm{P}$ whose residence time in mineral horizons is quite long due to its retention on soil constituents. Characteristically, the forest floor is abundantly colonized by roots (Brandtberg et al., 2004; Jackson et al., 1996), which allows close coupling of decomposition and uptake (Wood et al., 1984) and limits nutrient losses due to leaching or to retention on the mineral phase (Compton and Cole, 1998; Northup et al., 1995; Paré and Bernier, 1989). In addition, thick holorganic layers retain large quantities of plant available water (Leuschner, 1998).

Consequently, litter accumulation has two opposite effects on nutrient availability. On one hand, it temporarily sequestrates nutrients in decomposing and recalcitrant organic matter, and on the other hand, it creates a medium favorable for nutrient uptake. To better understand the role of the forest floor in $\mathrm{P}$ nutrition, we carried out a greenhouse experiment aiming at (i) comparing the $\mathrm{P}$ uptake of maritime pine seedlings growing either in mineral soil or in mineral soil covered with a forest floor layer and (ii) evaluating, within the latter treatment, the contribution of the forest floor to $\mathrm{P}$ supply using ${ }^{33} \mathrm{P}$ as isotopic label of the isotopically exchangeable phosphate ions of the mineral soil.

\section{MATERIALS AND METHODS}

\subsection{Experimental design}

Three-week-old maritime pine seedlings (Pinus pinaster Aït.) were planted in pots containing either mineral soil (MS) or mineral soil covered with a forest floor layer $(\mathrm{MS}+\mathrm{FF})$. The pots were placed in a greenhouse and distributed in five blocks according to a randomized block design. Three pots per treatment were included in each block since the maritime pine seedlings were harvested after three time periods (61, 95 and $130 \mathrm{~d}$ after planting). In addition, two control pots without seedlings (one for each treatment) were included in three out of the five blocks. The same design was used for a parallel experiment using ${ }^{33} \mathrm{P}$ as isotopic label of the isotopically exchangeable phosphate ions of the mineral soil. Thirty-six pots were used for the experiment without radioactivity, and 30 for the isotopic labeling experiment.

\subsection{Collection and processing of the growing media}

The growing media used for this study were collected at Biganos in the forest of the Landes de Gascogne (South West France; for more details see Augusto et al., 2006), an area where soils are known to be low in P (Trichet et al., 1999). The site classification, which includes various soil types and understory vegetation, depends mainly on the depth of the water table. The humid moorland is the more frequent site class of the forest (Trichet et al., 1999). In order to sample a soil representative for this forest, the mineral soil was taken from the A horizon $(0-20 \mathrm{~cm})$ of a sandy podzol in a pine stand planted on a humid moorland ( $44^{\circ} 40^{\prime} 36^{\prime \prime} \mathrm{N}, 00^{\circ} 56^{\prime} 49^{\prime \prime} \mathrm{W}$ ). The forest floor (mainly F layer) was collected in a nearby stand planted on a mesic moorland $\left(44^{\circ} 41^{\prime} 31^{\prime \prime} \mathrm{N}, 00^{\circ} 55^{\prime} 06^{\prime \prime} \mathrm{W}\right)$ with thick organic layers containing decaying litter of Pinus pinaster and Pteridium aquilinum. The mineral soil was sieved through a 8 by $8 \mathrm{~mm}$ mesh to remove roots and was then thoroughly mixed in bulk. The forest floor materials were coarsely ground (grate mesh size: $2 \mathrm{~cm}$ ) to break up pieces of litter held together by roots, and then mixed by hand.

\subsection{Characteristics of the growing media}

The collected mineral soil was sandy $(87.3 \%$ sand, $6.9 \%$ loam, $5.8 \%$ clay) and acidic ( $\left.\mathrm{pH} \mathrm{H}_{2} \mathrm{O}: 4.8\right)$ with a low base saturation (22\%) of the exchange complex (cobaltihexamine ECEC $=3.1 \mathrm{cmol}_{\mathrm{c}} \mathrm{kg}^{-1}$ ). The forest floor was also acidic $\left(\mathrm{pH} \mathrm{H}_{2} \mathrm{O}: 4.2\right)$ but its base saturation was $92 \%$ (cobaltihexamine ECEC $=26.6 \mathrm{cmol}_{\mathrm{c}} \mathrm{kg}^{-1}$ ). The total $\mathrm{C}$ content of the mineral soil was $29 \mathrm{mg} \mathrm{g}^{-1}$ and that of the forest floor $400 \mathrm{mg} \mathrm{g}^{-1}$. The total $\mathrm{N}$ content of the mineral soil was $1.3 \mathrm{mg} \mathrm{g}^{-1}$ and that of the forest floor $12.7 \mathrm{mg} \mathrm{g}^{-1}$. While the mineral soil contained amorphous free $\mathrm{Al}$ and $\mathrm{Fe}$ oxides extracted by the Tamm method ( $2.3 \mathrm{mg} \mathrm{Al} \mathrm{g}^{-1}$ and $2.6 \mathrm{mg} \mathrm{Fe} \mathrm{g}^{-1}$ ), there were few Al and Fe oxides in the forest floor $\left(0.4 \mathrm{mg} \mathrm{Al} \mathrm{g}^{-1}\right.$ and $\left.0.4 \mathrm{mg} \mathrm{Fe} \mathrm{g}^{-1}\right)$.

\subsection{P Status of the growing media}

Total $\mathrm{P}$ was determined by inductively coupled plasma spectrometry (ICP-AES) after combustion in a muffle furnace at $450{ }^{\circ} \mathrm{C}$ for $12 \mathrm{~h}$ and acid digestion with a mixture of $\mathrm{HF}$ and $\mathrm{HClO}_{4}$. Organic $\mathrm{P}$ 
was estimated by the difference between the $\mathrm{P}$ content extracted with $\mathrm{H}_{2} \mathrm{SO}_{4}(0.2 \mathrm{~N})$ for $16 \mathrm{~h}$ with and without prior combustion at $550{ }^{\circ} \mathrm{C}$ for $4 \mathrm{~h}$ (Saunders and Williams, 1955). Inorganic $\mathrm{P}$ was computed by subtracting organic P from total P-HF (Achat et al., 2009). The microbial $\mathrm{P}$ content of the forest floor material was determined using the chloroform fumigation method (Morel et al., 1996). Microbial P content was not determined for the mineral soil, but taken as the mean value of 11 similar soils from the same forest (Achat, 2009).

The dynamics of release and retention of $\mathrm{P}$ ions was characterized for the two growing media using the radio-isotopic labeling of $\mathrm{P}$ ions (with ${ }^{32} \mathrm{P}$ ), by determining the kinetics of isotopic dilution during a short-term batch experiment (Fardeau, 1993; 1996; Frossard and Sinaj, 1997). The method supposes that the $\mathrm{P}$ ions in solution are in equilibrium with the $\mathrm{P}$ ions retained on the solid phase and that the rate of $\mathrm{P}$ retention is equal to that of $\mathrm{P}$ release. Isotopic labeling is achieved by introducing a known amount of phosphate ions labelled with ${ }^{32} \mathrm{P}$ into the soil solution in a soil - solution system at chemical equilibrium.

According to the dilution principle, the gross amount of $\mathrm{P}$ ions transferred between the solution and the solid phase over a certain time $\left(P_{\mathrm{r}}\right.$ in $\left.\mathrm{mg} \mathrm{P} \mathrm{g}^{-1}\right)$ is determined based on the amount of $\mathrm{P}$ ions in solution $\left(P_{\mathrm{w}}\right.$ in $\left.\mathrm{mg} \mathrm{P}^{-1}\right)$ and on the isotopic composition of these $\mathrm{P}$ ions in solution $(I C)$.

$$
I C=\frac{r}{P_{\mathrm{w}}}=\frac{(R-r)}{P_{\mathrm{r}}}
$$

where $R$ is the quantity of ${ }^{32} \mathrm{P}$ introduced into the system and $r$ is the quantity of ${ }^{32} \mathrm{P}$ remaining in solution after a certain time.

Rearranging equation (1) gives:

$$
P_{\mathrm{r}}=\frac{P_{\mathrm{w}}}{r / R}-P_{\mathrm{w}}
$$

The total amount of isotopically exchangeable $\mathrm{P}\left(P_{\text {ex }}\right.$ in $\left.\mathrm{mg} \mathrm{P} \mathrm{g}^{-1}\right)$ is the sum of $P_{\mathrm{r}}$ and $P_{\mathrm{w}}$ (Hamon et al., 2002). For both growing media, $P_{\mathrm{r}}$ was determined for three time periods (4, 40 and $400 \mathrm{~min}$ ). Ten grams of mineral soil or $1 \mathrm{~g}$ of forest floor material (previously stored fresh at $4{ }^{\circ} \mathrm{C}$ ) were mixed with $0.2 \mathrm{~mL}$ of biocide (toluene) to avoid microbial development and with distilled water to obtain a final solution to substrate ratio of $15 \mathrm{~mL}: 10 \mathrm{~g}$ and $10 \mathrm{~mL}: 1 \mathrm{~g}$, respectively. All suspensions were pre-equilibrated for $16 \mathrm{~h}$ on a shaking table to reach a chemical equilibrium (constant $\mathrm{P}$ ion concentration in solution) for the subsequent hours during which isotopic dilution analysis was carried out. Carrier-free ${ }^{32} \mathrm{P}$ ions were added in the different suspensions at time zero. After 4, 40 and $400 \mathrm{~min}$, approximately $4 \mathrm{~mL}$ were taken up in all suspensions and filtered $(0.2 \mu \mathrm{m})$. The radioactivity introduced $(R)$ and that remaining in the filtered solution were counted together in a liquid scintillation cocktail (Insta-gel Plus Packard), using a liquid scintillation counter (TriCarb TR Packard). The inorganic $\mathrm{P}$ concentration in the filtered solution was determined by the molybdate and green malachite colorimetric method (Van Veldhoven and Mannaerts, 1987).

The temporal evolution of $P_{\mathrm{r}}$ was described by a kinetics equation (Morel et al., 2000) for $P_{\mathrm{r}}$ values inferior to total inorganic P minus $P$, considering that all inorganic $\mathrm{P}$ can take part in the isotopic dilution:

$$
P_{\mathrm{r}}=v \cdot t^{\mathrm{p}}
$$

where $t$ is the time in minutes, and $v$ and $p$ are parameters to fit. This equation was linearized and fitted with the MIXED procedure of the SAS software and then used to extrapolate $P_{\mathrm{r}}$ over time (Morel et al., 2000) and to calculate the time needed to reach its maximum value (total inorganic $P-P_{\mathrm{w}}$ ).

\subsection{Experimental setup}

For the two parallel experiments (with and without ${ }^{33} \mathrm{P}$ ), the pots (4 L, height: $20 \mathrm{~cm}$ ) were filled either with $2503 \mathrm{~g}$ of dry mineral soil (MS depth: $16 \mathrm{~cm}$ ) or with $1480 \mathrm{~g}$ of dry mineral soil and $236 \mathrm{~g}$ of dry forest floor material (FF depth: $6 \mathrm{~cm}+\mathrm{MS}$ depth: $10 \mathrm{~cm}$ ).

The mineral soil with ${ }^{33} \mathrm{P}$ was labeled by mixing a solution of carrier-free ${ }^{33} \mathrm{PO}_{4}$ ions $\left(2.1810^{5} \mathrm{~Bq} \mathrm{~mL}^{-1}\right)$ with the mineral soil at a rate of $20 \mathrm{~mL}$ solution per $\mathrm{kg}$ of dry soil. The principle of the labeling is an isotopic exchange of the ${ }^{33} \mathrm{PO}_{4}$-ions with the ${ }^{31} \mathrm{PO}_{4}$-isotopically exchangeable ions of the soil. To protect oneself against $\beta$ radiation and to avoid contamination by the radioactive soil, as well as to limit evaporation and stop grass from growing, a layer of acid-washed sand (pure quartz) was added to the surface of the pots after the seedlings were planted.

After a dormancy-breaking treatment ( 4 weeks at $4{ }^{\circ} \mathrm{C}$ ), 800 seeds of maritime pine originating from the Landes de Gascogne forest were sowed in containers filled with blond peat maintained at field capacity. The containers were placed in a growing chamber maintained at an air temperature of $24{ }^{\circ} \mathrm{C}$ and at $70 \%$ of relative humidity during the day $(15 \mathrm{~h})$ and at $19{ }^{\circ} \mathrm{C}$ and $65 \%$ of relative humidity during the night $(9 \mathrm{~h})$. After two weeks, the seedlings were sprayed with two fungicides (cryptonol and previcur, $2 \mathrm{ml} \mathrm{L}^{-1}$ ) to avoid damping off.

Twenty-three days after sowing (1st of March 2007), three seedlings of maritime pine (Pinus pinaster Aït.) were transplanted in each pot. The pots were placed in a greenhouse, which was heated for the first two months. During the experiment, the mean air temperature was $21.5{ }^{\circ} \mathrm{C}$ and the mean relative humidity $69 \%$. Six lamps were used to increase the photoperiod to $16 \mathrm{~h}$; the seedlings received a daily average of photosynthetically active radiation of 19.1 mole $\mathrm{m}^{-2} \mathrm{~d}^{-1}$. The mean temperature in the growing medium (sensors inserted $2 \mathrm{~cm}$ below the surface of the pot) was similar among treatments and among blocks (mean $=24.2{ }^{\circ} \mathrm{C}$ ). The pots were watered with permuted water and maintained at $70 \%$ of their maximum water holding capacity using an automated watering system (drip irrigation).

\subsection{Seedling harvest: biomass measurements}

The pine seedlings were harvested 61, 95 and $130 \mathrm{~d}$ after planting. The total height of all harvested seedlings was measured. The roots of the non-radioactive seedlings were extracted from the growing media and carefully washed with permuted water while those of the radioactive seedlings were left in the growing media. For each seedling, the biomass of the shoot (stem + needles) and of the roots (non-radioactive seedlings only) was determined after drying to constant weight at $105^{\circ} \mathrm{C}$.

\subsection{Measurement of roots and hyphae}

The roots of the non-radioactive seedlings were then divided into two components: the first corresponding to the roots contained either in the forest floor layer or in the upper part $(0-6 \mathrm{~cm})$ of the pots filled with mineral soil only, the second corresponding to the deeper mineral horizon in both kinds of pots $(6-16 \mathrm{~cm})$.

For all seedlings, total root length and mean diameter of both root components were measured with WinRHIZO software (Ver. 2005.A; Regent instruments, Quebec, Canada). 
The number of root tips per root length was used to estimate the ectomycorrhizal status of the seedlings assuming that all the root tips were colonized by ectomycorrhizal fungi (Bakker et al., 2006). We used WinRHIZO to estimate the number of root tips since Bakker et al. (2009) observed that the counts made by using WinRHIZO or a microscope (visual observation) were similar.

Mesh bags filled with sand were used to estimate the growth of ectomycorrhizal mycelia into the pots according to the method of Wallander et al. (2004). Two bags were placed horizontally in each pot, one in the upper horizon (containing either mineral soil or forest floor materials) and the other in the deeper horizon (mineral soil). The mesh bags ( 6 by $6 \mathrm{~cm}$ ) were sealed with a sewing machine. The mesh size $(30 \mu \mathrm{m})$ allowed the in-growth of fungal hyphae but prevented that of roots. The bags were filled with $30 \mathrm{~g}$ acid-washed sand $(<2 \mathrm{~mm})$ and sealed. As there was no organic matter in the sand, it was assumed that only mycorrhizal fungi developed within the bags (Wallander et al., 2001). Bakker et al. (2009) showed that $\delta^{13} \mathrm{C}$ values of extramatrical mycelia collected in sand bags incubated at $5 \mathrm{~cm}$ depth in an organo-mineral horizon were close to those of ectomycorrhizal carpophores, whereas the values for saprotrophic carpophores were different. The mesh bags placed in the upper and deeper horizons of the pots without radioactivity were collected at each harvest date and were stored at $4{ }^{\circ} \mathrm{C}$ before processing. The length of the hyphae inside the mesh bags was measured under a microscope as described by Wallander et al. (2004). Each mesh bag was opened in the laboratory. After mixing the sand, an aliquot of $15 \mathrm{~g}$ was introduced in $80 \mathrm{~mL}$ water and after 1 min shaking, a subsample $(5 \mathrm{~mL})$ was taken from the suspension and filtered. The filter was then stained with methylene blue. The length of the hyphae was measured using an ocular graticule, by counting the intersections between the grid and the hypha (Tennant, 1975).

\subsection{Determination of seedling nutrient concentrations}

Before performing the chemical analyses, the seedlings were separated into shoot and roots and then samples belonging to a same pot were pooled. Element analyses were carried out by inductively coupled plasma spectrometry $(\mathrm{P}, \mathrm{Ca}, \mathrm{K}, \mathrm{Mg}$ concentrations of nonradioactive seedlings) and colorimetry ( $\mathrm{P}$ concentration of the two kinds of seedlings) after combustion in a muffle furnace at $450{ }^{\circ} \mathrm{C}$ for $4 \mathrm{~h}$ and acid digestion with $\mathrm{HNO}_{3}(14 \mathrm{~N})$. The total $\mathrm{N}$ concentration of some samples (non-radioactive seedling shoots, third harvest date) was determined using a $\mathrm{CN}$ analyzer. Standard reference material (SRM 1575a, pine needles of Pinus taeda L.) of the National Institute of Standards and Technology in USA was used for quality control.

\subsection{Determination of specific activity}

When planning this experiment, we decided to evaluate the proportion of the $\mathrm{P}$ uptake originating from the mineral soil in the $\mathrm{MS}+\mathrm{FF}$ treatment by dividing the specific activity of the $\mathrm{P}$ uptake measured in this treatment by that obtained in the MS treatment (Di et al., 1997). Unfortunately, the P uptake in the MS treatment computed by subtracting the initial $\mathrm{P}$ content to the current $\mathrm{P}$ content remained insignificant at the three harvest dates and we were thus not able to estimate its specific activity by this method. For both treatments, we were however able to calculate the proportion of the shoot
$\mathrm{P}$ originating from the mineral soil $\left(\% P_{\text {shoot_MS }}\right)$ by dividing the specific activity of the shoot $\mathrm{P}\left(S A_{\text {shoot }}\right.$ in $\left.\mathrm{Bq} \mathrm{mg} P^{-1}\right)$ by the specific activity of the isotopically exchangeable phosphate ions contained in the mineral soil ( $S A_{\mathrm{MS}}$ in Bq mg $P^{-1}$; Morel and Plenchette, 1994).

$$
\% P_{\text {shoot_MS }}=\frac{S A_{\text {shoot }}}{S A_{\mathrm{MS}}}
$$

The shoot specific activity was obtained by dividing the shoot radioactivity $\left(R_{\text {seedling }}\right.$ in $\mathrm{Bq}$ seedling $\left.{ }^{-1}\right)$ by the shoot $\mathrm{P}$ content $\left(P_{\text {shoot }}\right.$ in mg seedling $\left.{ }^{-1}\right)$.

$$
S A_{\text {shoot }}=\frac{R_{\text {shoot }}}{P_{\text {shoot }}}
$$

The radioactivity of the solutions containing the mineralized radioactive shoots $\left(\mathrm{HNO}_{3} 0.74 \mathrm{~N}\right)$ was measured in a liquid scintillation cocktail $(9 \mathrm{~mL}$ mineralized solution mixed with $12 \mathrm{~mL}$ of Instagel Plus Packard), using a liquid scintillation counter (TriCarb TR Packard). In addition, the radioactivity of blank solutions was measured in mineralized solutions of non radioactive shoots and was used to correct the radioactivity measured in the radioactive solutions.

To determine the specific activity of the mineral soil, we assumed that the added ${ }^{33} \mathrm{P}$ was diluted in the isotopically exchangeable $\mathrm{P}$ pool due to physico-chemical reactions $\left(P_{\mathrm{ex}}\right.$, assessed with the batch experiment) and in the microbial $\mathrm{P}$ due to immobilization - remineralization processes (Achat, 2009; Walbridge and Vitousek, 1987). The amount of isotopically exchangeable $\mathrm{P}\left(P_{\mathrm{ex}}\right)$ increases with time until a maximum value which is supposed to be equal to the total amount of soil inorganic P (Fardeau, 1993). In this respect, the soils of the Landes de Gascognes are very particular and can reach the maximum amount of isotopically exchangeable P much more quickly than other soils (Achat et al., 2009). In our case, we estimated that an isotopic equilibrium was obtained after $24 \mathrm{~d}$; this time period was of the same magnitude order as the time that was needed by the pine seedlings to recover from transplanting. The specific activity of the mineral soil was thus considered constant during the whole experiment and was computed as the ratio between the radioactivity introduced in the soil $\left(R_{\text {soil }}\right.$ in $\left.\mathrm{Bq} \mathrm{g}^{-1}\right)$ and the sum of the maximum isotopically exchange-

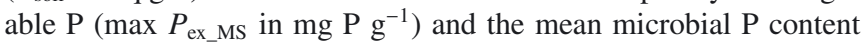
$\left(P_{\mu \_\mathrm{MS}}\right.$ in $\left.\mathrm{mg} \mathrm{P} \mathrm{g}^{-1}\right)$.

$$
S A_{\mathrm{MS}}=\frac{R_{\mathrm{soil}}}{\max P_{\text {ex_MS }}+P_{\mu \_\mathrm{MS}}}
$$

The radioactivity of the soil labeling solution was determined in the same matrix as the mineralized solutions. The counting was achieved at the same time (end of the experiment) for all the mineralized solutions and for the soil labeling solution in order to avoid quenching effects and to take the decay into account.

\subsection{Statistical and mathematical treatment of data}

A two-way ANOVA was performed to test for the effects of treatment and harvest date (and for their interaction) on the nutrient concentrations $(\mathrm{N}, \mathrm{P}, \mathrm{Ca}, \mathrm{Mg}, \mathrm{K})$ of the seedling shoots $(\alpha=0.05)$. The two treatments were compared at each date using contrasts. Within a given treatment, multiple comparison tests (Tukey) were used to test for differences between harvest dates. A similar procedure was used for biomass and for the $\mathrm{P}$ content of the seedling components (root, shoot, total), for P uptake, for root length and diameter, for the density of roots and hyphae and for root tips. Regarding root length 
Table I. Mean biomass and P content of the seedling components (shoot, root and total, $n=5$ ). Different letters indicate significant differences between the two treatments for the same harvest period. Different numbers indicate significant differences between harvest periods for the same treatment $(P<0.05)$. For the whole seedling (total), values in bold indicate significant differences from the initial value $(0 \mathrm{~d})$.

\begin{tabular}{|c|c|c|c|c|c|c|}
\hline & \multicolumn{2}{|c|}{ Shoot } & \multicolumn{2}{|c|}{ Root } & \multicolumn{2}{|c|}{ Total } \\
\hline & $\mathrm{MS}^{*}$ & $\mathrm{MS}+\mathrm{FF}^{*}$ & MS & $\mathrm{MS}+\mathrm{FF}$ & MS & $\mathrm{MS}+\mathrm{FF}$ \\
\hline \multicolumn{7}{|c|}{ Biomass $\left(\right.$ g seedling $^{-1}$ ) } \\
\hline $61 \mathrm{~d}$ & $0.27^{1 \mathrm{a}}$ & $0.31^{1 \mathrm{a}}$ & $0.14^{1 \mathrm{a}}$ & $0.12^{1 \mathrm{a}}$ & $0.41^{1 \mathrm{a}}$ & $0.44^{1 \mathrm{a}}$ \\
\hline $95 \mathrm{~d}$ & $0.31^{12 \mathrm{a}}$ & $0.70^{1 \mathrm{~b}}$ & $0.16^{12 \mathrm{a}}$ & $0.24^{2 b}$ & $0.47^{12 \mathrm{a}}$ & $0.94^{2 b}$ \\
\hline $130 \mathrm{~d}$ & $0.35^{2 \mathrm{a}}$ & $2.16^{2 b}$ & $0.19^{2 \mathrm{a}}$ & $0.55^{3 \mathrm{~b}}$ & $0.53^{2 \mathrm{a}}$ & $2.71^{3 b}$ \\
\hline $0 \mathrm{~d}$ & & & & & \multicolumn{2}{|c|}{0.21} \\
\hline $61 \mathrm{~d}$ & $0.14^{2 \mathrm{a}}$ & $0.33^{1 \mathrm{a}}$ & $0.08^{1 \mathrm{a}}$ & $0.09^{1 \mathrm{a}}$ & $0.22^{1 \mathrm{a}}$ & $0.43^{1 \mathrm{a}}$ \\
\hline $95 \mathrm{~d}$ & $0.11^{12 a}$ & $0.79^{1 b}$ & $0.08^{1 \mathrm{a}}$ & $0.23^{2 b}$ & $0.20^{1 \mathrm{a}}$ & $1.01^{2 b}$ \\
\hline $130 \mathrm{~d}$ & $0.10^{1 \mathrm{a}}$ & $1.68^{2 \mathrm{~b}}$ & $0.07^{1 \mathrm{a}}$ & $0.36^{3 b}$ & $0.18^{1 \mathrm{a}}$ & $2.03^{3 \mathrm{~b}}$ \\
\hline
\end{tabular}

* MS: mineral soil, MS+FF: mineral soil + forest floor.

$\dagger$ Number of days after planting.

and diameter, the density of roots and hyphae and root tips, the twoway ANOVA was performed separately for each horizon (upper and deeper). In addition, the horizon effect was evaluated for each date and for each treatment ( $t$ test). The statistical analyses were carried out with the MIXED procedure of SAS software (version 8.20; SAS institute Inc., Cary, N.C.).

For each harvest date, the $\mathrm{P}$ uptake of the MS+FF treatment was calculated for each horizon as follows:

$$
\text { Upper }+ \text { deeper horizon }: U P_{\mathrm{FF}+\mathrm{MS} \_\mathrm{j}}=P_{\text {seedling } \_\mathrm{j}}-P_{\text {seedling } \_0}
$$

Deeper horizon $: U P_{\mathrm{MS}_{\_} \mathrm{j}}=\% P_{\text {shoot_MS } \_\mathrm{j}} \cdot P_{\text {seedling } \_\mathrm{j}}$

$$
\text { Upper horizon }: U P_{\mathrm{FF}_{\lrcorner} \mathrm{j}}=U P_{\mathrm{FF}+\mathrm{MS}_{\lrcorner} \mathrm{j}}-U P_{\mathrm{MS}_{\lrcorner} \mathrm{j}}
$$

where $U P$ is the uptake per seedling ( $\mathrm{mg} P_{\text {seedling }}^{-1}$ ), MS and FF indicate the horizon concerned, $P_{\text {seedling }}$ is the $\mathrm{P}$ content of the seedling (mg $P_{\text {seedling }}^{-1}$ ), \% $P_{\text {shoot_Ms }}$ is the proportion of the shoot $\mathrm{P}$ content originating from the mineral soil and $j$ is the index for the harvest period.

Regarding the MS treatment, the P uptake estimated by subtracting the initial $\mathrm{P}$ content from the $\mathrm{P}$ content measured at the different harvest dates was not significantly different from zero. However, we estimated the $\mathrm{P}$ uptake by using the proportion of the $\mathrm{P}$ content originating from the mineral soil (Eq. (8)).

\section{RESULTS}

\subsection{Seedling growth and $P$ content}

At the first harvest date, the average stem height of 9.1 $( \pm 1.3) \mathrm{cm}$ was recorded and no differences were observed between treatments. The seedlings in the MS+FF treatment continued to grow at a sustained rate, and their stem height was $11.7( \pm 1.6)$ and $16.8( \pm 3.1) \mathrm{cm}$ at the second and third harvest dates, respectively. In contrast, there was a drastic reduction in growth of seedlings in the MS treatment.

At the first harvest date, the biomass components (shoot, root, total) did not significantly differ in the two treatments (Tab. I). At the second and third harvest dates, the total seedling biomass in the MS+FF treatment was respectively 2 and 5 times larger than in the MS treatment (Tab. I). The root to shoot biomass ratio was around 0.5 in the MS treatment and exhibited no temporal variation. In contrast, the root to shoot biomass ratio in the MS+FF treatment decreased from 0.39 (first harvest) to 0.25 (third harvest).

In the MS treatment, the total P content of the seedlings did not vary with time and remained at the level observed at planting throughout the experiment. In contrast, the total P content in the MS+FF treatment increased twofold, fivefold and tenfold at the first, second and third harvest dates, respectively. The proportion of $\mathrm{P}$ allocated to the roots was higher in the MS treatment (40\%) than in the MS+FF treatment (20\%).

\subsection{Root and ectomycorrhizal mycelium}

Like for stem height and biomass components, the total root length was similar in both treatments at the first harvest date. Subsequently, total root length stabilized in the MS treatment but continued to increase in the MS+FF treatment resulting in significant differences between treatments at the second and third harvest dates (Tab. II). Based on length, about $40 \%$ of the roots were located in the upper horizon and $60 \%$ in the deeper horizon; this proportion was not affected by the treatment (Tab. II).

Globally, the root diameter increased from the first to the third harvest date and was larger in the MS treatment than in the MS+FF treatment (Tab. II).

The number of root tips per root length was not affected by the treatment except for a higher value in the forest floor at the 
Table II. Root length, diameter and density, density of extramatrical mycelia and root tips in the two soil horizons (upper horizon: 0-6 cm depth, deeper horizon: 6-16 cm depth, $n=5$ ). Different letters indicate significant differences between treatments for the same harvest period. Different numbers indicate significant differences between harvest periods for the same treatment $(P<0.05)$. Values in italics for the deeper horizon indicate significant differences from the upper horizon.

\begin{tabular}{|c|c|c|c|c|c|c|c|c|c|c|}
\hline & \multicolumn{6}{|c|}{ Root } & \multirow{2}{*}{\multicolumn{2}{|c|}{$\begin{array}{c}\text { Extra-matrical mycelia } \\
\text { density }\left(\mathrm{cm} \mathrm{cm}^{-3}\right)\end{array}$}} & \multirow{2}{*}{\multicolumn{2}{|c|}{$\begin{array}{l}\text { Root tips } \\
\left(\mathrm{N} \mathrm{cm}^{-1}\right)\end{array}$}} \\
\hline & \multicolumn{2}{|c|}{ Length (cm seedling ${ }^{-1}$ ) } & \multicolumn{2}{|c|}{ Diameter (mm) } & \multicolumn{2}{|c|}{ Density $\left(\mathrm{cm} \mathrm{cm}^{-3}\right)$} & & & & \\
\hline & MS* & $\mathrm{MS}+\mathrm{FF}^{*}$ & MS & $\mathrm{MS}+\mathrm{FF}$ & MS & $\mathrm{MS}+\mathrm{FF}$ & MS & $\mathrm{MS}+\mathrm{FF}$ & MS & $\mathrm{MS}+\mathrm{FF}$ \\
\hline \multicolumn{11}{|c|}{ Upper horizon $(0-6 \mathrm{~cm})$} \\
\hline $61 \mathrm{~d}^{\dagger}$ & $98.7^{1 \mathrm{a}}$ & $131.5^{1 \mathrm{a}}$ & $0.78^{1 \mathrm{~b}}$ & $0.68^{1 \mathrm{a}}$ & $0.290^{1 \mathrm{a}}$ & $0.301^{1 \mathrm{a}}$ & $2.82^{1 \mathrm{a}}$ & $3.46^{12 \mathrm{a}}$ & $7.6^{1 \mathrm{a}}$ & $12.7^{1 \mathrm{~b}}$ \\
\hline $95 \mathrm{~d}$ & $100.7^{1 \mathrm{a}}$ & $202.2^{1 b}$ & $0.83^{1 b}$ & $0.69^{1 \mathrm{a}}$ & $0.295^{1 \mathrm{a}}$ & $0.463^{1 b}$ & $4.16^{1 \mathrm{a}}$ & $1.05^{1 \mathrm{a}}$ & $5.5^{12 \mathrm{a}}$ & $4.8^{2 \mathrm{a}}$ \\
\hline $130 \mathrm{~d}$ & $75.6^{1 \mathrm{a}}$ & $393.6^{2 b}$ & $1.11^{2 b}$ & $0.80^{2 \mathrm{a}}$ & $0.222^{1 \mathrm{a}}$ & $0.900^{2 b}$ & $2.23^{1 \mathrm{a}}$ & $8.13^{2 b}$ & $4.3^{2 \mathrm{a}}$ & $5.5^{2 \mathrm{a}}$ \\
\hline \multicolumn{11}{|c|}{ Deeper horizon $(6-16 \mathrm{~cm})$} \\
\hline $61 \mathrm{~d}$ & $138.3^{1 \mathrm{a}}$ & $199.5^{1 \mathrm{a}}$ & $0.76^{1 b}$ & $0.71^{12 \mathrm{a}}$ & $0.280^{1 \mathrm{a}}$ & $0.404^{1 \mathrm{a}}$ & $3.54^{1 \mathrm{a}}$ & $2.03^{1 \mathrm{a}}$ & $5.7^{1 \mathrm{a} *}$ & $5.8^{1 \mathrm{a} *}$ \\
\hline $95 \mathrm{~d}$ & $165.4^{1 \mathrm{a}}$ & $290.4^{1 b}$ & $0.75^{1 b}$ & $0.68^{1 \mathrm{a}}$ & $0.335^{1 \mathrm{a}}$ & $0.589^{1 \mathrm{~b}}$ & $2.53^{1 \mathrm{a}}$ & $1.66^{1 \mathrm{a}}$ & $4.3^{1 \mathrm{a}}$ & $4.4^{2 \mathrm{a}}$ \\
\hline $130 \mathrm{~d}$ & $167.0^{1 \mathrm{a}}$ & $643.1^{2 b}$ & $0.84^{2 b}$ & $0.76^{2 \mathrm{a}}$ & $0.338^{1 \mathrm{a}}$ & $1.303^{2 b}$ & $3.57^{1 \mathrm{a}}$ & $6.30^{1 \mathrm{a}}$ & $4.3^{1 \mathrm{a}}$ & $3.9^{2 \mathrm{a}}$ \\
\hline
\end{tabular}

* MS: mineral soil, MS+FF: mineral soil + forest floor.

$\dagger$ Number of days after planting.

Table III. Mean nutrient concentrations of the seedling shoots $(n=5)$. Different letters indicate significant differences between treatments for the same harvest period. Different numbers indicate significant differences between harvest periods for the same treatment $(P<0.05)$.

\begin{tabular}{|c|c|c|c|c|c|c|c|c|c|c|}
\hline & \multicolumn{2}{|c|}{$\mathrm{N}\left(\mathrm{mg} \mathrm{g}^{-1}\right)$} & \multicolumn{2}{|c|}{$\mathrm{P}\left(\mathrm{mg} \mathrm{g}^{-1}\right)$} & \multicolumn{2}{|c|}{$\mathrm{Ca}\left(\mathrm{mg} \mathrm{g}^{-1}\right)$} & \multicolumn{2}{|c|}{$\mathrm{Mg}\left(\mathrm{mg} \mathrm{g}^{-1}\right)$} & \multicolumn{2}{|c|}{$\mathrm{K}\left(\mathrm{mg} \mathrm{g}^{-1}\right)$} \\
\hline & MS $^{*}$ & $\mathrm{MS}+\mathrm{FF}^{*}$ & MS & $\mathrm{MS}+\mathrm{FF}$ & MS & $\mathrm{MS}+\mathrm{FF}$ & MS & $\mathrm{MS}+\mathrm{FF}$ & MS & $\mathrm{MS}+\mathrm{FF}$ \\
\hline $61 \mathrm{~d}^{\dagger}$ & & & $0.5^{3 \mathrm{a}}$ & $1.0^{1 \mathrm{~b}}$ & $1.4^{1 \mathrm{a}}$ & $1.1^{1 \mathrm{a}}$ & $1.5^{1 \mathrm{~b}}$ & $1.2^{1 \mathrm{a}}$ & $9.8^{3 \mathrm{a}}$ & $9.7^{2 \mathrm{a}}$ \\
\hline $95 \mathrm{~d}$ & & & $0.4^{2 \mathrm{a}}$ & $1.1^{1 \mathrm{~b}}$ & $1.5^{1 \mathrm{~b}}$ & $0.9^{1 \mathrm{a}}$ & $1.4^{1 \mathrm{~b}}$ & $1.0^{1 \mathrm{a}}$ & $7.8^{2 \mathrm{a}}$ & $7.4^{1 \mathrm{a}}$ \\
\hline $130 \mathrm{~d}$ & $24.1^{\mathrm{a}}$ & $19.9^{\mathrm{a}}$ & $0.3^{1 \mathrm{a}}$ & $0.8^{1 \mathrm{~b}}$ & $1.6^{1 \mathrm{~b}}$ & $1.1^{1 \mathrm{a}}$ & $1.4^{1 \mathrm{a}}$ & $1.1^{1 \mathrm{a}}$ & $6.5^{1 \mathrm{a}}$ & $7.2^{1 \mathrm{~b}}$ \\
\hline
\end{tabular}

* MS: mineral soil, MS+FF: forest floor + mineral soil.

$\dagger$ Number of days after planting.

first harvest date. In the upper horizon of both treatments, root tips decreased between the first and the second harvest dates (Tab. II). Regarding the density of external hyphae, no clear trend was observed, except for a higher value in the forest floor at the third harvest date. On average, this density was one order of magnitude (8 times) higher than root density (Tab. II).

\subsection{Shoot nutrient concentration}

At the third harvest date, the $\mathrm{N}$ concentration in the shoot was higher in the MS treatment than in the MS+FF treatment; this difference was however not significant (Tab. III). The P concentration in the shoot was twice higher in the MS+FF treatment than in the MS treatment; it decreased with time in the MS treatment, while it exhibited no temporal trend in the $\mathrm{MS}+\mathrm{FF}$ treatment. The Ca concentration in the shoot was significantly higher in the MS treatment than in the MS+FF treatment; no temporal trend was observed whatever the treatment. The $\mathrm{Mg}$ concentration in the shoot was also significantly higher in the MS treatment than in the MS+FF treatment; no temporal variation was observed whatever the treatment. The $\mathrm{K}$ concentration in the two treatments did not significantly differ from each other except at the third harvest date. In each treatment, the $\mathrm{K}$ concentration in the shoot decreased with time.
Table IV. P status of the two growing media (standard deviation).

\begin{tabular}{lcc}
\hline & Mineral soil & Forest floor \\
\hline Total $\mathrm{P}\left(\mathrm{mg} \mathrm{P} \mathrm{g}^{-1}\right)$ & $0.084(0.005)$ & $0.412(0.008)$ \\
Organic $\mathrm{P}\left(\mathrm{mg} \mathrm{P} \mathrm{g}^{-1}\right)$ & $0.048(0.001)$ & $0.395(0.009)$ \\
Microbial P $\left(\mathrm{mg} \mathrm{P} \mathrm{g}^{-1}\right)$ & $0.007(0.003)$ & $0.112(0.004)$ \\
Inorganic $\mathrm{P}$ in solution $\left(\mathrm{mg} \mathrm{P} \mathrm{g}^{-1}\right)$ & $1.2 \mathrm{E}-5(3.6 \mathrm{E}-6)$ & $2.2 \mathrm{E}-3(1.6 \mathrm{E}-4)$ \\
Gross amount of P ions exchanged & $0.0012 . \mathrm{t}^{0.33}$ & \\
in $t$ minutes $\left(\mathrm{mg} \mathrm{P} \mathrm{g}^{-1}\right)$ & & \\
\hline
\end{tabular}

\subsection{P status of the growing media}

At the beginning of the experiment, the total $\mathrm{P}$ content of the mineral soil was $0.084 \mathrm{mg} \mathrm{P} \mathrm{g}^{-1}$ and contained $57 \%$ of organic P; the remaining $43 \%$ was considered as inorganic P. According to the kinetics equation (Eq. (3)), the inorganic P pool was isotopically exchangeable in $24 \mathrm{~d}$. Within this pool, the $\mathrm{P}$ ions in solution represented an insignificant fraction (Tab. IV).

Regarding the forest floor, the total $\mathrm{P}$ content at the beginning of the experiment consisted mainly of organic $\mathrm{P}$ of which $27 \%$ of microbial P (Tab. IV). Based on the kinetics of isotopic dilution, we considered that there was no phosphate exchange 
Table V. Biomass and $\mathrm{P}$ concentration in radioactive shoots, radioactivity $\left(R_{\text {shoot }}\right)$, and specific activity $\left(S A_{\text {shoot }}\right)$ of the $\mathrm{P}$ contained in the shoots, specific activity of the isotopically exchangeable $\mathrm{P}$ ions of the mineral soil $\left(S A_{\mathrm{MS}}\right)$ and proportion of the shoot $\mathrm{P}$ originating from the mineral soil $\left(\% P_{\text {shoot_MS }}\right)$. Values in parentheses are standard deviation $(n=5)$.

\begin{tabular}{|c|c|c|c|c|c|c|}
\hline & $\begin{array}{l}\text { Shoot biomass } \\
(\mathrm{g} \text { seedling } \\
\end{array}$ & $\begin{array}{c}P_{\text {shoot }} \\
\left(\mathrm{mg} \mathrm{g}^{-1}\right)\end{array}$ & $\begin{array}{c}R_{\text {shoot }} \\
\left(\text { Bq seedling }^{-1}\right)\end{array}$ & $\begin{array}{c}S A_{\text {shoot }} \\
\left(\mathrm{Bq} \mathrm{mg} \mathrm{P}^{-1}\right)\end{array}$ & $\begin{array}{c}S A_{\mathrm{MS}} \\
\left(\mathrm{Bq} \mathrm{mg} \mathrm{P}^{-1}\right)\end{array}$ & $\begin{array}{c}\% P_{\text {shoot_MS }} \\
(\%)\end{array}$ \\
\hline \multicolumn{7}{|l|}{ MS } \\
\hline $61 \mathrm{~d}$ & $0.27(0.06)$ & $0.41(0.05)$ & $0.63(0.33)$ & $5.66(2.62)$ & 1054.66 & $0.54(0.25)$ \\
\hline $95 \mathrm{~d}$ & $0.30(0.05)$ & $0.29(0.04)$ & $0.93(0.47)$ & $10.31(3.67)$ & 1054.66 & $0.98(0.35)$ \\
\hline $130 \mathrm{~d}$ & $0.38(0.10)$ & $0.25(0.04)$ & $0.81(0.82)$ & $8.84(1.45)$ & 1054.66 & $0.84(0.14)$ \\
\hline \multicolumn{7}{|c|}{$\mathrm{FF}+\mathrm{MS}$} \\
\hline $61 \mathrm{~d}$ & $0.28(0.05)$ & $0.82(0.21)$ & $0.61(0.17)$ & $2.70(0.65)$ & 1054.66 & $0.26(0.06)$ \\
\hline $95 \mathrm{~d}$ & $0.70(0.17)$ & $1.43(0.37)$ & $4.24(0.62)$ & $4.49(0.95)$ & 1054.66 & $0.43(0.09)$ \\
\hline $130 \mathrm{~d}$ & $2.38(0.33)$ & $0.97(0.18)$ & $18.83(11.42)$ & $8.45(3.82)$ & 1054.66 & $0.80(0.36)$ \\
\hline
\end{tabular}

Table VI. P uptake in the two treatments. Values in parentheses are standard deviations $(n=5)$. Different letters indicate significant differences between harvest periods in the same column $(P<0.05)$.

\begin{tabular}{|c|c|c|c|}
\hline \multicolumn{4}{|c|}{ P uptake (mg seedling ${ }^{-1}$ ) } \\
\hline & \multirow{2}{*}{$\begin{array}{c}\text { MS treatment } \\
\text { Total }\end{array}$} & \multicolumn{2}{|c|}{ MS+FF treatment } \\
\hline & & FF horizon & MS horizon \\
\hline $61 \mathrm{~d}$ & $0.001^{\mathrm{a}}(0.0007)$ & $0.362^{\mathrm{a}}(0.212)$ & $0.001^{\mathrm{a}}(0.001)$ \\
\hline $95 \mathrm{~d}$ & $0.002^{\mathrm{a}}(0.0005)$ & $0.846^{\mathrm{a}}(0.209)$ & $0.005^{\mathrm{a}}(0.002)$ \\
\hline $130 \mathrm{~d}$ & $0.001^{\mathrm{a}}(0.0003)$ & $1.793^{\mathrm{b}}(0.665)$ & $0.016^{\mathrm{b}}(0.006)$ \\
\hline
\end{tabular}

between the solution and the solid phase of the forest floor and that all the inorganic $\mathrm{P}$ was in solution. Indeed, all the ${ }^{32} \mathrm{P}$ introduced in the forest floor suspensions remained in solution.

\section{5. $P$ uptake and contribution of the mineral soil to P supply}

$\mathrm{P}$ uptake in the MS treatment and in the two horizons of the MS+FF treatment was calculated from the seedling P content (Tab. I) and from the proportion of the $\mathrm{P}$ content originating from the mineral soil (Tab. V) using equations (7) to (9). P uptake in the MS treatment did not vary between harvest dates and was much lower than $\mathrm{P}$ uptake in the $\mathrm{MS}+\mathrm{FF}$ treatment which increased steadily with time (Tab. VI). In the $\mathrm{MS}+\mathrm{FF}$ treatment, the proportion of $\mathrm{P}$ uptake originating from the mineral soil was $0.5,0.6$ and $0.9 \%$ at the first, second and third harvest date, respectively (Tab. VI).

\section{DISCUSSION}

\subsection{Phosphorus, limiting factor for seedling growth}

Until the first harvest date, the maritime pine seedlings developed at the same rate in both treatments. However, in the MS treatment, the seedlings grew using the $\mathrm{P}$ stored in the seeds without being able to take up additional $\mathrm{P}$ from the mineral soil. In contrast, in the MS+FF treatment, the seedlings doubled their P content during the first period (Tab. I). During the rest of the experiment, seedling growth nearly stopped in the MS treatment (Tab. I) while it continued at a sustained rate in the MS+FF treatment. Similarly, Hallsby (1995) observed that spruce seedlings growing in forest floor materials developed two to three times faster than those growing in mineral soil. This contrasted growth pattern could theoretically be ascribed to higher water or nutrient availability in the MS+FF treatment. However, the soil moisture level maintained in the pots ( $70 \%$ of maximum water holding capacity) was chosen to avoid any water stress and to enable good soil aeration. Concerning mineral nutrition, the $\mathrm{N}, \mathrm{Ca}, \mathrm{Mg}$ and $\mathrm{K}$ nutritional status of the shoot seemed adequate in both treatments but was globally better for the seedlings in the MS treatment. In contrast, the P nutritional status of the shoot was lower in the MS treatment, and indicated a severe P deficiency (Tab. III).

The $\mathrm{P}$ deficiency of the seedlings growing in mineral soil is not surprising since the acid sandy soils (podzol) of the Landes de Gascogne are known to be poor in P (Augusto et al., 2006; Trichet et al., 1999). Pot experiments (Saur, 1989) and fertilization trials (Trichet et al., 2000; 2008) showed that P is the main limiting factor for tree growth in the forest of the Landes de Cascognes. Other limiting factors appear only when the P limitation has been removed (Trichet et al., 2008). In the present study, the pine seedlings (MS treatment) probably adjusted to the $\mathrm{P}$ limitation first by allocating more $\mathrm{C}$ to roots (Tab. I, Cheaib et al., 2005). However, as the deficiency was very pronounced, it is possible that photosynthesis was subsequently depressed (Loustau et al., 1999).

\subsection{Contributions of the forest floor to P supply}

At the end of the experiment, the forest floor had supplied $99.1 \%$ of the $\mathrm{P}$ immobilized in the seedlings in the MS+FF treatment (Tab. VI). In a field study using radioisotope techniques $\left({ }^{32} \mathrm{P}\right.$ and $\left.{ }^{33} \mathrm{P}\right)$, Brandtberg et al. (2004) reported that the contribution of the forest floor to the supply of $\mathrm{P}$ was respectively 93 and $95 \%$ in spruce and birch trees. 
In our study, the dominant contribution of the forest floor cannot be explained by more extensive root colonization of this growing medium or by a better development of the extramatrical mycelia. Indeed, the forest floor contained only $40 \%$ of the roots in the MS+FF treatment and the extramatrical mycelia developed very slowly in both treatments (Tab. II). The length of external hyphae expressed per unit of root length amounted to an average of $8\left(\mathrm{~m} \mathrm{~m}^{-1}\right)$ while values ranging from 500 to 8000 were reported by Read and Boyd (1986) and Rousseau et al. (1994). In the MS+FF treatment, the length of the external hyphae increased at the third harvest date, probably due to the good seedling development, enabling the translocation of carbohydrates to the mycorrhizal fungi (Black, 1988).

The capacity of the growing media to supply $\mathrm{P}$ to seedlings depended largely on their P-retention properties. In the forest floor, $100 \%$ of the isotopically exchangeable $\mathrm{P}$ was in solution and was therefore easily available for root absorption (Barber, 1995). However, this pool of exchangeable $P$ was subject to marked temporal variations since it was controlled by rapid biological processes such as mineralization of organic matter, immobilization in microbial biomass, and root uptake. In the mineral soil, more than $99 \%$ of the isotopically exchangeable $\mathrm{P}$ was bound to soil constituents and could be mobilized by depletion of the soil solution (Stroia et al., 2007). However, $\mathrm{P}$ transport by diffusion was very slow and did not enable a significant amount of $\mathrm{P}$ to be mobilized. Indeed, the $\mathrm{P}$ concentration gradient around the roots remained low since the inorganic P concentration in solution was very low (Yanai, 1994).

The differential P-retention capacity of the two growing media may be related to their contrasted contents of free Al and Fe oxides (Stevenson and Cole, 1999). In the mineral soil, these contents were at the upper ends of the ranges observed for the sandy podzols of the Landes de Gascogne (Al Tamm: 0.1-2.4 $\mathrm{mg} \mathrm{g}^{-1}$, Fe Tamm: 0.05-2.3 $\mathrm{mg} \mathrm{g}^{-1}$; Achat, 2009). The mineral soil used in this study was thus part of the more Pretentive soils of the Landes de Gascogne. Compared to other soil types, these soils have however a low ability to adsorb $\mathrm{P}$ (Achat et al., 2009). Globally, forest soils are generally acid with a high P-retention capacity (Attiwill and Adams, 1993); in this context, the accumulation of litter within the forest floor probably plays a major role in $\mathrm{P}$ nutrition.

Several authors have mentioned better nutrient status in stands exhibiting thicker holorganic layers. In a study including 48 radiata pine stands in New Zealand, Carey et al. (1982) showed that the $\mathrm{P}$ foliar concentration was positively correlated with the forest floor mass. In the Quebec Appalachians, Paré and Bernier (1989) observed that sugar maple stands growing on soils with mor humus had higher P foliar concentrations than soils with mull humus. Using long-term thinning trials in Norway spruce stands, Jonard et al. (2006) showed that an increase in the forest floor mass with stand basal area was accompanied by a parallel increase in the foliar $\mathrm{N}, \mathrm{P}$ and $\mathrm{K}$ concentrations. Except for $\mathrm{K}$, similar results were found by Merino et al. (2008) for beech in Spain. Comparing P cycling in Douglas fir and red alder stands, Compton and Cole (1998) observed that the higher $\mathrm{P}$ uptake in the red alder stand (4.3 vs. $2.7 \mathrm{~kg} \mathrm{ha}^{-1} \mathrm{y}^{-1}$ ) was associated with a larger $\mathrm{P}$ amount in the
O horizon (79 vs. $24 \mathrm{~kg} \mathrm{ha}^{-1}$ ) and a lower amount of available $\mathrm{P}$ in the mineral soil (4 vs. $44 \mathrm{~kg} \mathrm{ha}^{-1}$ ).

It is worth mentioning that the effects of the forest floor on $\mathrm{P}$ nutrition can also vary with climate conditions. During periods of drought, the forest floor may be strongly affected. In this context, its capacity to supply $\mathrm{P}$ could be limited by its low water content. Conversely, the presence of the forest floor slows down the drying of the underlying horizons.

\section{CONCLUSION}

Conventional wisdom in forestry considers that nutrient immobilization in thick forest floors lowers site productivity. On its own, this point of view oversimplifies the function of the forest floor for tree nutrition and can lead to counterproductive management guidelines. In acid mineral soils, $\mathrm{P}$ uptake is limited since the high P-retention capacity of the soil solid phase maintains the concentration of inorganic $\mathrm{P}$ in solution at a very low level. In this context, the accumulation of decomposing litter creates an alternative medium with low P-retention capacity that allows close coupling of litter decomposition and root uptake. If this biological control of $\mathrm{P}$ availability is disrupted, it is likely that large amounts of $\mathrm{P}$ migrate from the forest floor to the underlying mineral horizons (Wood et al., 1984). Recovery of the $\mathrm{P}$ transferred in the mineral horizons as a result of a disturbance (such as plowing before plantation) may take a few decades and forest growth may be reduced during this period. Where $\mathrm{P}$ is a limiting factor for tree growth, foresters are therefore recommended to use practices that preserve the forest floor.

Acknowledgements: We would like to thank A. Schneider and M. Linères for helpful discussions and useful advice, C. Barbot and L. Prudhomme for expert technical assistance. Mathieu Jonard acknowledges the department 'Écologie des Forêts, Prairies et milieux Aquatiques' of INRA for his post-doctoral fellowship and the 'Fond Spécial de Recherche' for an additional grant to cover travel costs.

\section{REFERENCES}

Achat D.L., 2009. Biodisponibilité du phosphore dans les sols landais pour les peuplements forestiers de pin maritime. Ph.D. thesis, Université de Bordeaux 1, Bordeaux, France, $291 \mathrm{p}$.

Achat D.L., Bakker M.R., Augusto L., Saur E., and Morel C., 2009. Evaluation of the phosphorus status of highly P-deficient spodosols in temperate pine stands: combining isotopic dilution and extraction methods. Biogeochemistry (in press).

Attiwill P.M. and Adams M.A., 1993. Tansley review No. 50. Nutrient cycling in forests. New Phytol. 124: 561-582.

Augusto L., Badeau V., Arrouays D., Trichet P., Flot J.L., Jolivet C., and Merzeau D., 2006. Caractérisation physico-chimique des sols à l'échelle d'une région naturelle à partir d'une compilation de données. Exemple des sols du massif forestier landais. Etude et Gestion des Sols 13: 7-22.

Bakker M.R., Augusto L., and Achat D.L., 2006. Fine root distribution of trees and understory in mature stands of maritime pine (Pinus pinaster) on dry and humid sites. Plant Soil 286: 37-51.

Bakker M.R., Jolicoeur E., Trichet P., Augusto L., Plassard C., Guinberteau J., and Loustau D., 2009. Adaptation of fine roots to annual fertilization and irrigation in a 13-year-old Pinus pinaster stand. Tree Physiol. (in press). 
Barber S.A., 1995. Soil Nutrient Bioavailability: A Mechanistic approach, John Wiley \& Sons, New York, 398 p.

Berg B. and McClaugherty C., 2003. Plant litter: decomposition, humus formation, carbon sequestration, Springer-Verlag, Berlin, Germany, $286 \mathrm{p}$.

Black C.H., 1988. Interaction of phosphorus fertilizer form and soil medium on Douglas-fir seedling phosphorus content, growth and photosynthesis. Plant Soil 106: 191-199.

Brandtberg P.O., Bengtsson J., and Lundkvist H., 2004. Distributions of the capacity to take up nutrients by Betula spp. and Picea abies in mixed stands. For. Ecol. Manage. 198: 193-208.

Carey M.L., Hunter I.R., and Andrew I., 1982. Pinus radiata forest floors: factors affecting organic matter and nutrient dynamics. N. Z. J. For. Sci. 12: $36-48$

Chapin F.S., 1980. The mineral nutrition of wild plants. Ann. Rev. Ecol. Syst. 11: 233-260.

Cheaib A., Mollier A., Thunot S., Lambrot C., Pellerin S., and Loustau D., 2005. Interactive effects of phosphorus and light availability in early growth of maritime pine seedlings. Ann. For. Sci. 62: 575-583.

Compton J.E. and Cole D.W., 1998. Phosphorus cycling and soil P fractions in Douglas-fir and red alder stands. For. Ecol. Manage. 110: $101-112$.

Di H.J., Condron L.M., and Frossard E., 1997. Isotope techniques to study phosphorus cycling in agricultural and forest soils: a review. Biol. Fertil. Soils 24: 1-12.

Fardeau J.C., 1993. Le phosphore biodisponible du sol. Un système pluricompartimental à structure mamellaire. Agronomie 1: 1-13.

Fardeau J.C., 1996. Dynamics of phosphate in soils. An isotopic outlook. Fert. Res. 45: 91-100.

Fisher R.F. and Binkley D., 2000 Ecology and management of forest soils, 3rd ed., John Wiley \& Sons, Inc., USA, 489 p.

Frossard E. and Sinaj S., 1997. The isotope exchange kinetics technique: a method to describe the availability of inorganic nutrients. Applications to K, P, S and Zn. Isot. Environ. Health. Stud. 33: 61-77.

Jackson R.B., Canadell J., Ehleringer J.R., Mooney H.A., Sala O.A., and Schulze E.D., 1996. A global analysis of root distributions for terrestrial biomes. Oecologia 108: 389-411.

Jonard M., Misson L., and Ponette Q., 2006. Long-term thinning effects on the forest floor and the foliar nutrient status of Norway spruce stands in the Belgian Ardennes. Can. J. For. Res. 36: 2684-2695.

Hallsby G., 1995. Influence of Norway spruce seedlings on the nutrient availability in mineral soil and forest floor material. Plant Soil 173: $39-45$.

Hamon R.E., Bertrand I., and McLaughlin M.J., 2002. Use and abuse of isotopic exchange data in soil chemistry. Aust. J. Soil Res. 40: 13711381.

Kimmins J.P., 1997. Forest ecology: a foundation for sustainable forest management, 2nd ed., Prentice and Hall, Upper Saddle River, New Jersey, $596 \mathrm{p}$.

Leuschner C., 1998. Water extraction by tree fine roots in the forest floor of a temperate Fagus-Quercus forest. Ann. Sci. For. 55: 141-157.

Loustau D., Ben Brahim M., Gaudillère J.P., and Dreyer E., 1999. Photosynthetic responses to phosphorus nutrition in two-year-old maritime pine seedlings. Tree Physiol. 19: 707-715.

Merino A., Real C., and Rodriguez-Guitian M., 2008. Nutrient status of managed and natural forest fragments of Fagus sylvatica in southern Europe. For. Ecol. Manage. 255: 3691-3699.

Morel C. and Plenchette C., 1994. Is the isotopically exchangeable phosphate of a loamy soil the plant-available P? Plant Soil 158: 287-297.

Morel C., Tiessen H., and Stewart J.W.B., 1996. Correction for P-sorption in the measurement of soil microbial biomass by $\mathrm{CHCl}_{3}$ fumigation. Soil Biol. Biochem. 28: 1699-1706.
Morel C., Tunney H., Plénet D., and Pellerin S., 2000. Transfer of phosphate ions between soil and solution. Perspectives in soil testing. J. Environ. Qual. 29: 50-59.

Northup R.R., Dahlgren R.A., and Yu Z., 1995. Intraspecific variation of conifer phenolic concentration on a marine terrace soil acidity gradient; a new interpretation. Plant Soil 171: 255-262.

Paré D. and Bernier B., 1989. Origin of the phosphorus deficiency observed in declining sugar maple stands in the Quebec Appalachians. Can. J. For. Res. 19: 24-34.

Polglase P.J., Attiwill P.M., and Adams M.A., 1992. Nitrogen and phosphorus cycling in relation to stand age of Eucalyptus regnans $\mathrm{F}$. Muell. III. Labile inorganic and organic P, phosphatase activity and P availability. Plant Soil 142: 177-185.

Read D.J. and Boyd R., 1986. Water relations of mycorrhizal fungi and their host plants. In: Ayres P. and Boddy L. (Eds.), Water, fungi and plants, Cambridge University Press, Cambridge, pp. 287-303.

Rousseau J.V.D., Sylvia D.M., and Fox A.J., 1994. Contribution of ectomycorrhiza to the potential nutrient-absorbing surface of pine. New Phytol. 128: 639-644.

Saunders W.M.H. and Williams E.G., 1955. Observations on the determination of total organic phosphorus in soils. J. Soil Sci. $6: 254-267$.

Saur E., 1989. Effet de l'apport de phosphore, de carbonate de calcium et d'oligo-éléments $(\mathrm{Cu}, \mathrm{Mn}, \mathrm{Zn}, \mathrm{B})$ à trois sols sableux acides sur la croissance et la nutrition de semis de Pinus pinaster Soland in Ait. I. Croissance et nutrition en éléments majeurs. Agronomie 9: 931-940.

Stevenson F.J. and Cole M.A., 1999. Cycles of soil, 2nd ed., John Wiley \& Sons, USA, $637 \mathrm{p}$.

Stroia C., Jouany C., and Morel C., 2007. Effect of pooling soil samples on the diffusive dynamics of phosphate ionic species. Soil Sci. 172: 614-622.

Tennant D., 1975. A test of a modified line intersect method of estimating root length. J. Ecol. 63: 995-1001.

Trichet P., Jolivet C.I., Arrouays D., Loustau D., Bert D., and Ranger J., 1999. Le maintien de la fertilité des sols forestiers landais dans le cadre de la sylviculture intensive du pin maritime. Revue bibliographique et identification des pistes de recherches. Étude et Gestion des Sols 6: 197-214.

Trichet P., Vauchel F., Bert D., and Bonneau M., 2000. Fertilisation initiale et réitérée du pin maritime (Pinus pinaster Aït.): principaux résultats de l'essai de Berganton. Rev. For. Fr. 52: 207-222.

Trichet P., Loustau D., Lambrot C., and Linder S., 2008. Manipulating nutrient and water availability in a maritime pine plantation: effects on growth, production, and biomass allocation at canopy closure. Ann. For. Sci. 65: 814.

Van Veldhoven P.V. and Mannaerts G.P., 1987. Inorganic and organic phosphate measurements in the nanomolar range. Anal. Biochem. 161: 45-48.

Walbridge M.R. and Vitousek P.M., 1987. Phosphorus mineralization potentials in acid organic soils: processes affecting ${ }^{32} \mathrm{PO}_{4}^{3-}$ isotope dilution measurements. Soil Biol. Biochem. 19: 709-717.

Wallander H., Nilsson L.O., Hagerberg D., and Baath E., 2001. Estimation of the biomass and seasonal growth of external mycelium of ectomycorrhizal fungi in the field. New Phytol. 151: 753-760.

Wallander H., Goransson H., and Rosengren U., 2004. Production, standing biomass and natural abundance of ${ }^{15} \mathrm{~N}$ and ${ }^{13} \mathrm{C}$ in ectomycorrhizal mycelia collected at different soil depths in two forest types. Oecologia 139: 89-97.

Wood T., Bormann F.H., and Voigt G.K., 1984. Phosphorus cycling in a northern hardwood forest: biological and chemical control. Science 233: 391-393.

Yanai R.D., 1994. A steady-state model of nutrient uptake accounting for newly grown roots. Soil Sci. Soc. Am. J. 58: 1562-1571. 